\title{
Lipid-zinc interaction: its effect on the testes of mice
}

\author{
BY S. K. TANEJA, S. CHADHA AND P. ARYA \\ Department of Zoology, Panjab University, Chandigarh-160 014 India
}

(Received 22 December 1993-Revised 16 August 1994-Accepted 5 October 1994)

\begin{abstract}
Lipid-Zn interaction in the testes of mice was studied by feeding them low-fat ( $30 \mathrm{~g}$ maize oil/kg; group LFZD) and high-fat ( $90 \mathrm{~g}$ maize oil/kg; group HFZD) Zn-deficient diets for 6 weeks. The results were compared with those of corresponding Zn-supplemented-diet-fed controls (groups LFZS and HFZS). The integument-related Zn-deficiency symptoms appeared in group HFZD and not in group LFZD mice despite lack of $\mathrm{Zn}$ in their ration and an equal level of $\mathrm{Zn}$ in their blood serum. The feed intake, gain in body weight and testes weight of the LFZD group were comparable with those of the LFZS and HFZS groups $(P>0.05)$ but were higher than those of the group HFZD $(P<0.05)$. The testes of group HFZD displayed necrotic changes marked by the presence of giant cells, lower RNA, DNA and protein concentrations and higher phospholipid and cholesterol levels than those of mice in the LFZD group. The concentrations of these fractions were not significantly different between LFZD and HFZS. The results do not support the hypothesis that $\mathrm{Zn}$ is essential either for testicular function or for nucleic acid and protein synthesis in animals fed on a low-fat diet; however, it appears to be essential for animals fed on a high-fat diet. The changes observed in the testes of the HFZD animals suggest the excess intake of fat as their cause in $\mathrm{Zn}$-deficient animals.
\end{abstract}

Lipid: Zinc: Lipid-zinc interaction: Testes: Mice

Sterility as one of the symptoms of $\mathrm{Zn}$ deficiency has been reported in all mammalian species including man (Millar et al. 1958; Prasad et al. 1961; Bieri \& Prival, 1966; Sandstead et al. 1967; Halstead et al. 1972; Abbasi et al. 1976; Lee et al. 1976; Underwood, 1977; Taneja \& Nirmal, 1980; Golden \& Golden, 1981; Walravens et al. 1983; Prasad \& Cossack, 1984; Haschke et al. 1985; McClain et al. 1985; Reeves, 1990). Smaller testes, loss of tubular size, nuclear chromatolysis in germ cells, arrest of spermatozoa and depletion of Leydig cells are the pathological changes that have been reported in the testes of severely Zn-deficient mammals (Perizek et al. 1966; Swenerton \& Leucille, 1968; Somers \& Underwood, 1969; Underwood \& Somers, 1969; Taneja \& Nirmal, 1980). These degenerative changes have been correlated either with the defects in nucleic acid, protein (Macapinlac et al. 1968; Somers \& Underwood, 1969; Terhune \& Sandstead, 1972) and fat metabolism (Bieri \& Prival, 1966; Clejan et al. 1982; Chanmugam et al. 1984) or with the hormonal disorders involving pituitary gonadotropins and testosterone (Lei et al. 1976; Underwood, 1977; McClain et al. 1984). Underwood (1977) suggested that the hormonal changes might be secondary to inanition and growth retardation effects caused by $\mathrm{Zn}$ deficiency. Taneja \& Arya (1992) observed that the low feed intake and growth retardation effects caused by $\mathrm{Zn}$ deficiency were ameliorated by restricting the fat content to $30 \mathrm{~g} / \mathrm{kg}$ in a $\mathrm{Zn}$-deficient basal diet. This suggests that a high lipid content in a $\mathrm{Zn}$-deficient diet is responsible for the induction of these symptoms and possibly may influence the testicular function so widely reported in $\mathrm{Zn}$-deficient mammals. This led us to investigate the effect of high- and low-fat $\mathbf{Z n}$-deficient and $\mathbf{Z n}$-supplemented diets on the testes of mice. 


\section{MATERIALS AND METHODS}

\section{Dietary treatment}

Adult male mice of the lacca strain ( $n$ 40) weighing $21-25 \mathrm{~g}$ were obtained from the Central Animal House of the Panjab University, Chandigarh, India and maintained according to the guidelines approved by the Ethics Committee of the Panjab University, Chandigarh. They were divided randomly into four groups, ten in each group, and housed in plastic cages in a room maintained at $22-27^{\circ}$. Group LFZD was fed on a purified semisynthetic (Table 1) low-lipid, Zn-deficient ( $30 \mathrm{~g}$ maize oil $/ \mathrm{kg}, 0.5-1.0 \mu \mathrm{g} \mathrm{Zn} / \mathrm{g}$ ) diet, group LFZS was given a low-lipid Zn-supplemented ( $30 \mathrm{~g}$ maize oil $/ \mathrm{kg}, 20 \mu \mathrm{g} \mathrm{Zn} / \mathrm{g}$ ) diet, group HFZD was given a high-lipid, $\mathrm{Zn}$-deficient $(90 \mathrm{~g}$ maize oil $/ \mathrm{kg}, 0.5-1.0 \mu \mathrm{g} \mathrm{Zn} / \mathrm{g}$ ) diet and group HFZS was given a high-lipid, Zn-supplemented ( $90 \mathrm{~g}$ maize oil $/ \mathrm{kg}, 20 \mu \mathrm{g} \mathrm{Zn} / \mathrm{g}$ ) diet. All the animals were fed ad lib. on their respective diets for 6 weeks and doubledistilled deionized water was made freely available to them.

A record of feed intake and body weights was maintained on a weekly basis.

After the 6 weeks of dietary treatment, six animals of each group were lightly anaesthetized with diethyl ether and the testes and blood were removed and processed for the bioassay.

\section{Estimation of zinc}

$\mathrm{Zn}$ concentrations in the serum of six animals of each group were estimated separately by atomic absorption spectrophotometry (Model 306, Perkin Elmer; Norwalk, CT, USA) after digesting $0.1 \mathrm{ml}$ serum in nitric acid-perchloric acid $(3: 1, \mathrm{v} / \mathrm{v})$.

\section{Histology}

The testes of four mice from each group were cut into small pieces. They were fixed in Zenker's and formalin-calcium fluids. The Zenker's-fluid-fixed tissue was processed for paraffin sectioning and stained in delafield haematoxylin and eosin. The formalin-calciumfixed tissue was postchromed and processed for gelatin sections on a cold microtome. Thin $(7 \mu \mathrm{m})$ gelatin sections were stained in Sudan Black B and acid haematein for the localization of total lipids and phospholipids respectively (Pearse, 1985).

Table 1. Compositions of the high-and low-fat diets for mice $(\mathrm{g} / \mathrm{kg})^{*} \dagger$

\begin{tabular}{lrr}
\hline \hline Ingredient & High-fat & Low-fat \\
\hline EDTA-washed casein & 300 & 300 \\
Agar & 15 & 15 \\
Maize oil & 90 & 30 \\
Cellulose & 80 & 140 \\
Sucrose & 430 & 430 \\
Vitamin mixtureł & 50 & 50 \\
Mineral mixture§ & 35 & 35 \\
\hline
\end{tabular}

* Each diet was modified to be zinc-deficient or zinc-supplemented by the addition of $\mathrm{ZnSO}_{4} .7 \mathrm{H}_{2} \mathrm{O}$ as given on p. 724 .

$\uparrow$ The diets were stored in separate sealed sterilized glass bottles in a deep freezer at $-8^{\circ}$ until use.

$\$$ Contained (mg/g vitamin mixture): ascorbic acid 100 , biotin 0.5 , calcium pantothenate 50 , choline chloride 500 , pteroylglutamic acid $0 \cdot 15$, inositol 200 , menadione 4 , nicotinic acid 65 , pyridoxine hydrochloride 5 , riboflavin 20 , thiamine hydrochloride 50 , tocopherol acetate 6 , cyanocobalamin 0.01 , ergocalciferol 0.0031, retinol 0.03 .

$\S$ Contained (g/kg diet): $\mathrm{CaHPO}_{4} 25 \cdot 8, \mathrm{CoCl}_{2} .6 \mathrm{H}_{2} \mathrm{O} 0 \cdot 04, \mathrm{CuCl}_{2} 0.06, \mathrm{FeSO}_{4} .7 \mathrm{H}_{2} \mathrm{O} 0.06, \mathrm{MnSO}_{4} . \mathrm{H}_{2} \mathrm{O}$ $0 \cdot 4, \mathrm{MgSO}_{4}, \mathrm{H}_{2} \mathrm{O} 4 \cdot 05, \mathrm{KCl} 3 \cdot 43, \mathrm{KI} 0 \cdot 004, \mathrm{Na}_{2} \mathrm{CO}_{3} 1 \cdot 16, \mathrm{NaF} 0 \cdot 006$. 
Estimation of DNA, RNA and proteins

A $100 \mathrm{mg}$ portion of testes in each case was homogenized for the extraction of DNA, RNA and proteins by Schneider's method (1945). Protein was estimated by the method of Lowry et al. (1951). DNA was estimated by the method of Bradshaw (1966) and RNA was estimated by Mejbaum's (1939) modified method based on the orcinol reaction.

\section{Estimation of total lipids, phospholipids and cholesterol}

The total lipids were extracted following the method of Folch et al. (1957) and the colorimetric method of Frings \& Dunn (1970) was employed for the estimation of total lipids. Phospholipids were assayed by the method of Zilversmit \& Davis (1950). The ferric chloride method of Chiamori \& Henry (1959) was employed for the estimation of cholesterol.

\section{Biostatistics}

The data collected were subjected to statistical analysis by a two-way ANOVA test (Daniel, 1983). The significance between the variants was determined by $F$ test and was considered significant when the $P$ values were $<0.05$.

\section{RESULTS}

\section{Morphological changes}

The integument-related Zn-deficiency symptoms started appearing in HFZD mice after 3 weeks of dietary treatment and became more prominent as the duration of feeding was prolonged. The symptoms included the greying of hair, appearance of spiny hair coat, loss of hair, dermatitis near the toes, nails and anal region. These symptoms were lacking in the animals of the LFZD group and the LFZS and HFZS groups.

The feed intake in group HFZD was significantly lower compared with those of groups LFZD, LFZS and HFZS. The animals of group HFZD consumed 20-25\% less diet than those of groups LFZD, LFZS and HFZS (see Table 2). The total feed intake per week was identical in groups LFZD and LFZS but was slightly higher than that of group HFZS.

\section{Gain in body weight}

The gain in body weight recorded at the end of each week has been depicted in Fig. 1. A steep growth curve up to week 3 followed by a plateau was observed in group LFZS. Groups LFZD and HFZS showed a rather gradual increase in their body weights over weeks 1-6 although the percentage gain in body weight was less in comparison with that of group LFZS (Table 2). In contrast, the body weight of group HFZD remained almost constant during weeks $1-3$ and started declining gradually during the following weeks.

\section{Weight of testes}

The testicular weight per $\mathrm{kg}$ body weight between groups LFZD and HFZD differed significantly $(P<0.05)$, being lower in the latter group (Table 2), while it was not significantly different between groups LFZD, LFZS and HFZS $(P>0.05)$.

\section{Histology}

The testes of groups LFZD, LFZS and HFZS did not display any abnormality in the germcell population of the seminiferous tubules. They were healthy and the stages of spermatogenesis were distinctly marked in the sections stained with delafield haematoxylin and eosin. However, the testes of group HFZD mice exhibited some degenerative changes marked by the presence of giant cells, lying in the lumen and in between the germ cells, wavy theca albuginea and the presence of fatty deposits, positive to Sudan Black B and acid 


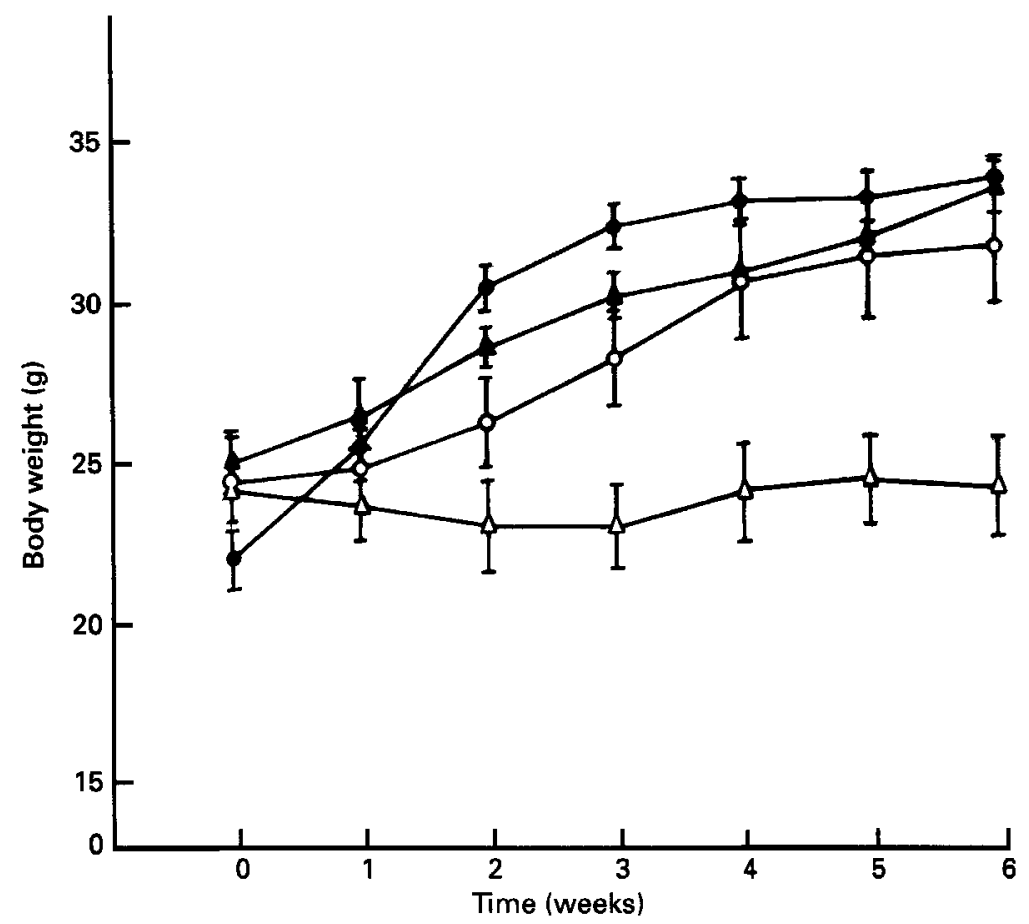

Fig. 1. Change over time in the body weight of mice fed on low-lipid, zinc-deficient (O), low-lipid, zincsupplemented $(\mathcal{O})$, high-lipid, zinc-deficient $(\triangle)$ and high-lipid, zinc-supplemented $(\boldsymbol{\Delta})$ diets. Values are means for ten mice with standard deviations indicated by vertical bars. For details of diets, see Table 1.

Table 2. Initial body weight, final body weight, feed intake, percentage change in body weight and testis weight in mice fed on low-fat and high-fat diets that were deficient in, or supplemented with, zinc*

(Mean values with their standard errors for ten mice)

\begin{tabular}{|c|c|c|c|c|c|c|}
\hline Groups & $\begin{array}{l}\text { Initial } \\
\text { body } \\
\text { wt }(\mathrm{g})\end{array}$ & $\begin{array}{l}\text { Final } \\
\text { body } \\
\text { wt }(g)\end{array}$ & $\begin{array}{c}\text { Mean feed } \\
\text { intake } \\
\text { (g/kg body wt) }\end{array}$ & $\begin{array}{l}\text { Change } \\
\text { in body } \\
\text { wt }(\%)\end{array}$ & $\begin{array}{c}\text { Mean } \\
\text { testis } \\
\text { wt (mg) }\end{array}$ & $\begin{array}{c}\text { Mean wt of } \\
\text { testis } \\
(\mathrm{mg} / \mathrm{kg} \text { body wt) }\end{array}$ \\
\hline LFZD & $24 \cdot 36$ & $31 \cdot 27$ & $95 \cdot 7^{a}$ & $+28 \cdot 27^{\mathrm{a}}$ & $97 \cdot 64$ & $3216 \cdot 7^{a}$ \\
\hline $\mathrm{SE}$ & $1 \cdot 0$ & $1 \cdot 74$ & 0.5 & $0 \cdot 37$ & 2.582 & 58.3 \\
\hline LFZS & $23 \cdot 90$ & $33 \cdot 27$ & $95 \cdot 4^{a}$ & $+38 \cdot 10^{\mathrm{b}}$ & $109 \cdot 27$ & $3296 \cdot 5^{\mathrm{a}}$ \\
\hline $\mathrm{SE}$ & 0.732 & 0.681 & 0.009 & 0.31 & 1.432 & $39 \cdot 0$ \\
\hline HFZD & $24 \cdot 36$ & $24 \cdot 0$ & $77 \cdot 8^{\mathrm{c}}$ & $-1 \cdot 48^{\mathrm{c}}$ & $66 \cdot 09$ & $2854 \cdot 3^{\mathrm{b}}$ \\
\hline SE & 0.902 & 1.423 & 0.08 & 0.056 & $1 \cdot 20$ & $42 \cdot 1$ \\
\hline HFZS & $25 \cdot 0$ & 33.73 & $89 \cdot 6^{b}$ & $+34 \cdot 96^{\mathrm{b}}$ & 106.91 & $3184 \cdot 4^{a}$ \\
\hline $\mathrm{SE}$ & 0.761 & 0.834 & $0 \cdot 13$ & 0.21 & 0.99 & $57 \cdot 9$ \\
\hline
\end{tabular}

LFZD, low-fat, zinc-deficient ; LFZS, low-fat, zinc-supplemented; HFZD, high-fat, zinc-deficient; HFZS, highfat, zinc-supplemented.

a.b.e Mean values within a column not sharing a common superscript letter were significantly different $(P<0.05)$.

* For details of diets and procedures, see Table 1 and p. 724. 
Table 3. Serum zinc concentration, and protein, DNA and RNA concentrations in the testes of mice fed on low-fat and high-fat diets which were either deficient in, or supplemented with, zinc*

(Mean values with their standard errors for six mice)

\begin{tabular}{cccccc}
\hline Groups & $\begin{array}{c}\text { Serum Zn } \\
(\mu \mathrm{g} / \mathrm{ml})\end{array}$ & $\begin{array}{c}\text { Protein } \\
(\mathrm{mg} / \mathrm{g} \text { tissue } \\
\text { wt) }\end{array}$ & $\begin{array}{c}\text { DNA } \\
(\mathrm{mg} / \mathrm{mg} \\
\text { protein) }\end{array}$ & $\begin{array}{c}\text { RNA } \\
(\mathrm{mg} / \mathrm{mg} \\
\text { protein) }\end{array}$ & RNA/DNA \\
\hline LFZD & $0.624^{\mathrm{a}}$ & $291 \cdot 1^{\mathrm{a}}$ & $0.13^{\mathrm{b}}$ & $0.054^{\mathrm{c}}$ & $0.42^{\mathrm{c}}$ \\
SE & 0.027 & 4.85 & 0.004 & 0.002 & 0.002 \\
LFZS & $0.924^{\mathrm{b}}$ & $301 \cdot 1^{\mathrm{a}}$ & $0.13^{\mathrm{b}}$ & $0.064^{\mathrm{b}}$ & $0.48^{\mathrm{b}}$ \\
SE & 0.058 & 4.34 & 0.005 & 0.002 & 0.022 \\
HFZD & $0.623^{\mathrm{a}}$ & $252.6^{\mathrm{b}}$ & $0.11^{\mathrm{a}}$ & $0.059^{\mathrm{a}}$ & $0.57^{\mathrm{a}}$ \\
SE & 0.018 & 9.18 & 0.011 & 0.003 & 0.044 \\
HFZS & $0.893^{\mathrm{b}}$ & $292.4^{\mathrm{a}}$ & $0.12^{\mathrm{b}}$ & $0.057^{\mathrm{a}}$ & $0.48^{\mathrm{b}}$ \\
SE & 0.097 & 7.56 & 0.005 & 0.002 & 0.024 \\
\hline \hline
\end{tabular}

LFZD, low-fat, zinc-deficient; LFZS, low-fat, zinc-supplemented; HFZD, high-fat, zinc-deficient; HFZS, highfat, zinc-supplemented.

$a, b, c$ Mean values within a column not sharing a common superscript letter were significantly different $(P<0.05)$.

* For details of diets and procedures, see Table 1 and pp. 724-725.

haematein tests, concentrated mostly in spermatogonia of many of the seminiferous tubules. Some of these tubules appeared healthy.

\section{Zinc concentration}

The serum $\mathrm{Zn}$ concentration was not significantly different between groups LFZD and HFZD and between LFZS and HFZS $(P>0-05)$. Group LFZS showed an increase of $48.1 \%$ compared with the LFZD group $(P<0.05)$; and group HFZD registered a decrease of $30.2 \%$ compared with that of group HFZS $(P<0.05)$.

\section{Extractable proteins}

The protein fractions in groups HFZS, LFZD and LFZS were not significantly different amongst one another $(P>0 \cdot 05)$ but were all significantly higher than that of group HFZD $(P<0.01$; Table 3$)$.

\section{Nucleic acids}

The DNA fractions of the testes in diet groups LFZD, LFZS and HFZS were almost identical (Table 3), but were significantly higher than that of group HFZD $(P<0.001)$.

The RNA concentration in group HFZD was slightly higher than those of groups LFZD and HFZS but lower than that of group LFZS. However the RNA:DNA ratio in group HFZD was the highest compared with those of the other three groups (Table 3 ).

\section{Total lipid, phospholipids and cholesterol}

The total lipid fraction in the testes of mice fed on LFZS, HFZD and HFZS diets did not differ significantly but it was significantly lower in the mice fed on the LFZD diet $(P<0.05)$ than in those of the other three groups (Table 4). The phospholipid and cholesterol fractions were also identical in groups LFZD and HFZS $(P>0.05)$ but were significantly lower than that of group HFZD $(P<0.001)$. Amongst the four dietary groups, the lowest concentrations were obtained in the group fed on the LFZS diet (Table 4). Similar results were found for the cholesterol:phospholipid molar ratio. 
Table 4. Concentrations of total lipid, phospholipid and cholesterol in the testes of mice fed on low-fat and high-fat diets that were either deficient in, or supplemented with, zinc*

(Mean values with their standard errors for six mice)

\begin{tabular}{|c|c|c|c|c|}
\hline Groups & $\begin{array}{c}\text { Total lipids } \\
(\mathrm{mg} / \mathrm{mg} \text { protein) }\end{array}$ & $\begin{array}{l}\text { Phospholipids } \\
\text { (mg/mg protein) }\end{array}$ & $\begin{array}{c}\text { Cholesterol } \\
\text { (mg/mg protein) }\end{array}$ & $\begin{array}{c}\text { Cholesterol: } \\
\text { phospholipid } \\
\text { molar ratio }\end{array}$ \\
\hline LFZD & $6 \cdot 26^{a}$ & $0.235^{\mathrm{b}}$ & $0.019^{b}$ & $0 \cdot 156^{\mathrm{b}}$ \\
\hline SE & 0.231 & 0.009 & 0.001 & 0.003 \\
\hline LFZS & $7 \cdot 56^{\mathrm{b}}$ & $0.066^{c}$ & $0.004^{c}$ & $0 \cdot 114^{c}$ \\
\hline SE & $0 \cdot 308$ & 0.003 & 0.001 & 0.01 \\
\hline HFZD & $7 \cdot 67^{b}$ & $0 \cdot 345^{\mathrm{a}}$ & $0.030^{\mathrm{a}}$ & $0 \cdot 178^{a}$ \\
\hline $\mathbf{S E}$ & 0.721 & 0.015 & 0.002 & 0.007 \\
\hline HFZS & $7 \cdot 55^{b}$ & $0.222^{\mathrm{d}}$ & $0.017^{\mathrm{b}}$ & $0 \cdot 158^{b}$ \\
\hline $\mathbf{S E}$ & 0.358 & 0.008 & 0.001 & 0.015 \\
\hline
\end{tabular}

LFZD, low-fat, zinc-deficient ; LFZS, low-fat, zinc-supplemented; HFZD, high-fat, zinc-deficient; HFZS, highfat, zinc-supplemented.

a,b,e,d Mean values within a column not sharing a common superscript letter were significantly different $(P<0.05)$.

* For details of diets and procedures, see Table 1 and pp. 724-725.

\section{DISCUSSION}

Alopecia, dermatitis, anorexia and growth retardation as Zn-deficiency symptoms appeared in the mice fed on the high-lipid Zn-deficient diet (group HFZD) in accordance with the observations of Prasad et al. (1961); Sandstead et al. (1967); Hurley (1969); Koo \& Williams (1981); Petering et al. (1982); Essatara et al. (1984a,b); Giugliano \& Millward (1984); McClain et al. (1984); Moran \& Lyerly (1985) and Taneja et al. (1990). However the mice fed on the low-lipid, Zn-deficient diet (group LFZD) did not exhibit these symptoms. Their fur coat, growth and feed intake were similar to those fed on LFZS and HFZS diets. The close similarity between the mice of groups LFZD, LFZS and HFZS does not support the idea that the induction of symptoms is primarily related to $\mathrm{Zn}$ deficiency. $\mathrm{Had} \mathrm{Zn}$ been the sole factor responsible for the induction of symptoms in the mice fed on $\mathrm{Zn}$-deficient diets, then symptoms should have appeared in both high- and low-lipid Zndeficient groups (i.e. LFZD and HFZD diet groups) and not in group HFZD alone. The difference between the two groups was in the level of fat and not in the level of $\mathrm{Zn}$ in the diet. Their $\mathrm{Zn}$ concentration in serum being identical, the excess lipid in diet group HFZD appears to have been responsible for the induction of $\mathrm{Zn}$-deficiency-related symptoms. This is in accordance with our earlier report (Taneja \& Arya, 1992). We reported that the symptoms appeared in mice when fed on a $\mathrm{Zn}$-deficient diet containing cod-liver oil $(30 \mathrm{~g} / \mathrm{kg})$ and maize oil $(60 \mathrm{~g} / \mathrm{kg})$ as the lipid source and they disappeared, despite $\mathrm{Zn}$ deficiency, when the maize oil was withdrawn from the $\mathrm{Zn}$-deficient diet. The similarity of the results between the present study and the one reported previously (Taneja \& Arya, 1992) clarifies that the quantity rather than quality of the fat induces the symptoms in $\mathrm{Zn}$ deficient mice.

Associated with the reduction of body weight, significantly lower testes weights in the animals of group HFZD are in conformity with the observations of previous investigators who fed fat at $50 \mathrm{~g} / \mathrm{kg}$ or above in the basal diet (Millar et al. 1958; Bieri \& Prival, 1966; Sandstead et al. 1967; Abbasi et al. 1976; Lei et al. 1976; Underwood, 1977; Taneja \& Nirmal, 1980; McClain et al. 1984; Reeves, 1990). The pathological changes in the testes of mice of group HFZD marked by the presence of giant cells and their absence in group 
LFZD reflected the onset of the process of degeneration in group HFZD and not in group LFZD despite the identical level of $\mathrm{Zn}$ concentration in the blood serum. The severe damage in the testes per se as reported by many investigators who employed weanling rats was not witnessed in the mice in the present study. We employed mature mice that require 8 weeks of dietary treatment for complete testicular atrophy (Taneja \& Nirmal, 1980). The present experiment was deliberately terminated after 6 weeks to ascertain the involvement of $\mathrm{Zn}$ in testicular function rather than to obtain the net pathological information.

The testicular degenerative changes in $\mathrm{Zn}$-deficient animals have been correlated with the reductions in DNA, RNA and protein concentrations (Macapinlac et al. 1968; Somers \& Underwood, 1969; Underwood \& Somers, 1969; Terhune \& Sandstead, 1972) attributing the defects in the nucleic acids and protein metabolism as their cause. The lower concentrations of DNA and protein in the testes of the mice fed on the HFZD diet than those fed on the HFZS diet were also observed by us. Almost identical concentrations of DNA and protein in groups LFZD and HFZS, despite a lower $\mathrm{Zn}$ concentration in the serum of the former than the latter group but equal to that of group HFZD, do not support the possibility of the involvement of $\mathrm{Zn}$ in the DNA and protein metabolism leading to the arrest of spermatogenesis.

Further, the concentration of total lipid did not change significantly in the testes of groups LFZS, HFZD and HFZS. Bieri \& Prival (1966) and Clejan et al. (1981), however, reported a higher concentration of total lipid along with phospholipid and cholesterol in $\mathrm{Zn}$-deficient than in $\mathrm{Zn}$-supplemented rats. Higher concentrations of cholesterol and phospholipid were also observed by us in group HFZD compared with those of group LFZD. Their concentrations in the LFZD group were almost identical to those in group HFZS. Since the rise of phospholipid and cholesterol concentrations in the testes has been reported to be associated with the impairment of testicular function (Bieri \& Prival, 1966; Gambal \& Ackerman, 1967; Nakamura et al. 1968; Johnson, 1970), the present results suggest that the defects in testicular function occurred only in group HFZD and not in group LFZD despite both groups having equal concentrations of $\mathrm{Zn}$ in their blood serum. This is contrary to earlier reports suggesting essentiality of $\mathrm{Zn}$ for testicular functions. (Millar et al. 1958; Bieri \& Prival, 1966; Abbasi et al. 1976; Lei et al. 1976; Taneja \& Nirmal, 1980; McClain et al. 1985; Reeves, 1990). The lower concentrations of total lipid, phospholipids and cholesterol in the testes of LFZS than in HFZS and LFZD groups might be due to their faster utilization in the former than in the latter two groups which, in fact, was evidenced by the highest testicular weight in group LFZS.

The low feed intake, loss of body weight and impairment of testicular function appeared only in response to $\mathrm{Zn}$-deficiency coupled with a high fat concentration in the diet and not in response to a low fat concentration in the diet. In the absence of $\mathrm{Zn}$ in the diet, lipid has been observed to accumulate in the mucosal epithelial cells of the intestine of rats (Koo \& Turk, 1977), mice (Taneja \& Arya, 1992) and carp (Cyprinus carpio; Taneja et al. 1990). Based on electron microscopic studies, Koo \& Turk (1977) reported that the nascent chylomicrons in the $\mathrm{Zn}$-deficient rats lost their stability and coalesced to form bigger droplets that were unable to pass to the lacteals. Their transport from the intestine to the lacteals was reduced drastically as estimated from olive oil uptake by the intestine. Lipid deposition in the intestinal mucosal epithelial cells causes an inhibition of stomach emptying and gastric secretion through a feedback mechanism in rats (Konturek \& Grossman, 1965; Long \& Brooks, 1965). A similar mechanism appears to operate in mice as well which we determined by estimating the feed intake and stomach clearance in mice fed on a high-fat Zn-deficient diet (Taneja \& Arya, 1992). It also exacerbated the malabsorption of nutrients by interfering with the intestinal uptake mechanism which we concluded by estimating $\left[{ }^{14} \mathrm{C}\right]$ glucose uptake (Taneja \& Arya, 1992). The anorexia and 
malabsorption of $\left[{ }^{14} \mathrm{C}\right]$ glucose were not evident when the mice were given a low-lipid $\mathrm{Zn}$ deficient diet or a high-fat, $\mathrm{Zn}$-supplemented diet. The feed intake and growth rate in them were identical, as was the case in the present study.

This implies that $\mathrm{Zn}$ in the diet promotes the transport of lipid from enterocytes to the lacteals facilitating the movement of other nutrients from the lumen of the intestine to the blood, and explains the higher body weight and testes weight in group LFZS than group LFZD. The lower growth rate and lower testes weight in mice fed on the HFZS diet than those fed on the LFZS diet may be the result of the suboptimal $\mathrm{Zn}$ : fat ratio in their diet.

The results of the present study, therefore, suggest that $\mathrm{Zn}$ is not essential for testicular function in mice fed on a diet containing $30 \mathrm{~g}$ fat $/ \mathrm{kg}$ but is of prime importance when the diet is rich in fat. The requirement for $\mathrm{Zn}$ in the diet seems to depend upon the level of dietary fat. The malfunctioning of testes in mice fed on the HFZD diet was due to the excess fat intake which required $\mathrm{Zn}$ for its utilization.

\section{REFERENCES}

Abbasi, A. A., Prasad, A. S., Ortega, J., Congco, E. \& Oberleas, D. (1976). Gonadal function abnormalities in sickle cell anemia. Studies in adult male patients. Annals of Internal Medicine 85, 601-605.

Bieri, J. G. \& Prival, E. L. (1966). Effect of deficiencies of alpha tocopherol, retinol and zinc on lipid composition of rat testes. Journal of Nutrition 89, 55-63.

Bradshaw, L. J. (1966). Introduction to Molecular Biology Technique, pp. 135-137. New Jersey: Prentice Hall Inc.

Chanmugam, P., Wheeler, C. \& Hwang, D. H. (1984). The effect of zinc deficiency on prostaglandin synthesis in rat testes. Journal of Nutrition 114, 2066-2072.

Chiamori, N. \& Henry, R. J. (1959). Study of the ferric chloride method for determination of total cholesterol and cholesterol esters. American Journal of Clinical Pathology 31, 305-309.

Clejan, S., Castro-Magana, M., Collipp, P. J., Jonas, E. \& Maddaiah, V. T. (1982). Effects of zinc deficiency and castration on fatty acid composition and desaturation in rats. Lipids 17, $129-135$.

Clejan, S., Maddaiah, V. T., Castro-Magana, M. \& Collipp, P. J. (1981). Zinc deficiency-induced changes in the composition of microsomal membranes and in the enzymatic regulation of glycerolipid synthesis. Lipids 16, $454-460$.

Daniel, W. W. (1983). Biostatistics: A Foundation for Analysis in the Health Sciences, 3rd ed., pp. 77-87. New York: John Wiley \& Sons.

Essatara, M. B., McClain, C. J., Levine, A. S. \& Morley, J. E. (1984a). Zinc deficiency and anorexia in rats: the effect of central administration of norepinephrine muscimol and bromerogocryptine. Physiology and Behavior 32, 479-482.

Essatara, M. B., Morley, J. E., Levine, A. S., Elson, M. K., Shafar, R. B. \& McClain, C. J. (1984b). The role of endogenous opiates in zinc deficiency anorexia. Physiology and Behavior 32, 475-478.

Folch, J. L. M., Lees, M. \& Sloane-Stanley, G. H. (1957). A simple method for the isolation and purification of total lipids from animal tissues. Journal of Biological Chemistry 226, 497-509.

Frings, C. S. \& Dunn, R. T. (1970). A colorimetric method for determination of total serum lipids based on sulfophospho-vanillin reaction. American Journal of Clinical Pathology 53, 89-91.

Gambal, D. \& Ackerman, R. J. (1967). Hormonal control of rat testicular phospholipids. Endocrinology 80, 231-239.

Golden, M. H. H. \& Golden, B. E. (1981). Effects of zinc supplementation on the dietary intake, rate of weight gain and energy cost of tissue deposition in children recovering from severe malnutrition. American Journal of Clinical Nutrition 34, 900-908.

Giugliano, R. \& Millward, D. J. (1984). Growth and zinc homeostasis in severely Zn-deficient rats. British Journal of Nutrition 52, 545-560.

Halstead, J. A., Ronaghy, H. A., Abadi, P., Hagshenass, M., Amirhakenii, G. H., Barakat, R. M. \& Reinhold, J. G. (1972). Zn-deficiency in man. The Shiraz experiment. American Journal of Medicine 53, $277-284$.

Haschke, F., Singer, P., Baumgartner, D., Steffan, I., Schiling, R. \& Lothallar, H. (1985). Growth, zinc and copper nutritional status of male premature infants with different zinc intake. Annals of Nutrition and Metabolism 29, 95-102.

Hurley, L. S. (1969). Zinc deficiency in the developing rat. American Journal of Clinical Nutrition 22, $1332-1339$.

Johnson, A. D. (1970). Testicular lipids. In The Testis, Vol. 2, Biochemistry, pp. 193-258 [A. D. Johnson, W. R. Gomes and N. L. Vandermark, editors]. New York: Academic Press.

Konturek, S. \& Grossman, M. I. (1965). Effect of perfusion of intestinal loops with acid, fat or dextrose on gastric secretion. Gastroenterology 4, 481-489.

Koo, S. I. \& Turk, D. E. (1977). Effect of zinc deficiency on intestinal transport of triglyceride in the rat. Journal of Nutrition 107, 909-919. 
Koo, S. I. \& Williams, D. A. (1981). Relationship between nutritional status of zinc and cholesterol concentration of serum lipoproteins in adult male rats. American Journal of Clinical Nutrition 34, 2376-2381.

Lei, K. Y., Abbasi, A. \& Prasad, A. S. (1976). Function of pituitary-gonadal axis in zinc-deficient rats. American Journal of Physiology 230, 1730-1732.

Long, J. F. \& Brooks, F. P. (1965). Relation between inhibition of gastric secretion and absorption of fatty acids. American Journal of Physiology 209, 447-451.

Lowry, O. H., Rosebrough, M. J., Farr, A. L. \& Randall, R. J. (1951). Protein measurement with Folin-phenol reagent. Journal of Biological Chemistry 238, 3955-3962.

Macapinlac, M. P., Pearson, W. N., Barney, G. H. \& Darby, W. J. (1968). Protein and nucleic acid metabolism in the testes of zinc-deficient rats. Journal of Nutrition 95, 569-577.

McClain, C. J., Gavaler, J. S. \& Van Thiel, D. H. (1984). Hypogonadism in the zinc-deficient rat: localization of the functional abnormalities. Journal of Laboratory and Clinical Medicine 104, 1007-1015.

McClain, C. J., Kasarskis, E. J. Jr \& Allen, J. J. (1985). Functional consequences of zinc deficiency. Progress in Food and Nutrition Science 9, 185-226.

Mejbaum, W. J. (1939). Estimation of small amounts of pentose especially in derivatives of adenylic acid. Zeitschrift für Physiologisch Chemie 258, 117-121.

Millar, M. J., Fischer, M. I., Elocate, P. V. \& Mawson, C. A. (1958). Effect of dietary zinc deficiency on reproductive system of male rats. Canadian Journal of Biochemistry and Physiology 36, 557-569.

Moran, J. R. \& Lyerly, A. (1985). The effects of severe zinc deficiency on intestinal amino acid losses in the rat. Life Sciences 36, 2515-2521.

Nakamura, M., Jensen, B. \& Privett, O. S. (1968). Effect of hypophysectomy on fatty acids and lipid classes of rat testes. Endocrinology 82, 137-142.

Pearse, A. G. E. (1985). Histochemistry - Theoretical and Applied, vol. 2, pp. 830-838. London: Churchill Livingstone.

Perizek, J., Bourshell, J. C., May, M. F., Babicky, A. \& Taylor, D. M. (1966). Zinc in the maturing rat testes. Journal of Reproduction and Fertility 12, 501-507.

Petering, H. G., Giroux, E., Choudhry, H. \& Menden, E. E. (1982). Consecutive zinc balance trials in growing rats. Biological Trace Elements Research 4, 221-232.

Prasad, A. S. \& Cossack, Z. T. (1984). Zinc supplementation and growth in sickle cell disease. Annals of Internal Medicine 100, 367-371.

Prasad, A. S., Halstead, J. A. \& Nadimi, M. (1961). Syndrome of iron deficiency anemia, hepatosplenomegaly, hypogonadism, dwarfism and geophagia. American Journal of Medicine 31, 532-546.

Reeves, P. G. (1990). Zinc deficiency and dipeptidyl carboxypeptidase activity. Comparative effects on epididymis and testis of rats. Biological Trace Elements Research 24, 1-11.

Sandstead, H. H., Prasad, A. S., Schubert, A. R., Farid, Z., Miale, A., Bassily, S. \& Darby, S. J. (1967). Human zinc deficiency, endocrine manifestations and response to treatment. American Journal of Clinical Nutrition 20, 422-441.

Schneider, W. C. (1945). Phosphorus compounds in animal tissues. Extraction of nucleic acid and of pentose nucleic acid. Journal of Biological Chemistry 161, 293-303.

Somers, M. \& Underwood, E. J. (1969). Ribonuclease activity and nucleic acid and protein metabolism in the testes of zinc-deficient rats. Australian Journal of Biological Sciences 22, 1277-1282.

Swenerton, H. \& Lucille, S. H. (1968). Severe zinc deficiency in male and female rats. Journal of Nutrition $95,8-18$.

Taneja, S. K. \& Arya, P. (1992). Influence of low dietary lipid content on anorexia and $\left[{ }^{14} \mathrm{C}\right] \mathrm{glucose}$ uptake in the intestine of zinc-deficient mice. British Journal of Nutrition 68, 505-514.

Taneja, S. K., Lath, A. \& Arya, P. (1990). Lipid malabsorption as a possible cause of anorexia in zinc-deficient common carp (Cyprinus carpio). Aquaculture 89, 327-335.

Taneja, S. K. \& Nirmal (1980). Histopathology of testes of mice fed on zinc-deficient diet. Indian Journal of Experimental Biology 18, 1411-1414.

Terhune, M. W. \& Sandstead, H. H. (1972). Decreased RNA polymerase activity in mammalian zinc deficiency. Science 177, 68-69.

Underwood, E. J. (1977). Trace Elements in Human and Animal Nutrition, 3rd ed., pp. 222-236. [A. S. Prasad and D. Oberleas, editors]. New York: Academic Press.

Underwood, E. J. \& Somers, M. (1969). Studies of zinc nutrition in sheep. 1. The relation of zinc to growth, testicular development and spermatogenesis in young rats. Australian Journal of Agricultural Research 20, 889-897.

Walravens, P. A., Krebs, N. F. \& Hambridge, K. M. (1983). Linear growth of low income preschool children receiving a zinc supplement. American Journal of Clinical Nutrition 38, 195-201.

Zilversmit, D. B. \& Davis, A. K. (1950). Micromethod of phospholipid by trichloroacetic acid precipitation. Journal of Laboratory and Clinical Medicine 36, 265-270. 